the coast, while breeding herds travelled from South Laikipi to the Aberdare mountains, then north-east to the Lorian swamps, north-west to Marsabit, and south again to the Aberdares - the round-trip of $650 \mathrm{~km}$ taking some three years.

\section{SUMMARY}

Ecological interrelationships are far less complex in the desert biome than they are in grassland or forest but, even so, they are little understood. Some of the better known are described, but none of them is relevant to desertification. Harmful insects, such as locusts, grasshoppers, and termites, are unlikely to be responsible for extension of desert, except when they intensify environmental changes that have already been initiated by Man. Similarly, mammalian herbivores, even if protected and allowed to attain far greater population sizes than at present, are most unlikely to cause harm, as they are highly nomadic and always on the move.

These relationships hold true despite the fact that the natural predators of desert mammalian herbivores have largely been eliminated by human activities.

\section{References}

Baharov, D. (1974). Notes on the population structure and biomass of the Mountain Gazelle, Gazella gazella gazella. Israel J. Zool., 23, pp. 39-44, 4 figs.

Bourlière, F. (1965). Densities and biomasses of some ungulate populations in Eastern Congo and Rwanda, with notes on population structure and lion/ungulate ratios. Zool. Africana, 1, pp. 199-207.

BrINCK, P. (1956). The food factor in animal desert life. Pp. 120 37 in Bertil Hanstrom: Zoological Papers in Honour of his 65th Birthday, November 20th 1956 (Ed. K. G. Wingstrang). Zool. Inst., Lund, Sweden: 312 pp., illustr.

Buxton, P. A. (1923). Animal Life in Deserts. Edward Arnold, London: $\mathrm{xv}+176 \mathrm{pp}$., illustr.

Cloudsley-Thompson, J. L. (1977a). Reclamation of the Sahara. Environmental Conservation, 4(2), pp. 115-9, 4 figs.

Cloudsley-Thompson, J. L. (1977b). Man and the Biology of Arid Zones. Edward Arnold, London: ix +182 pp., illustr.

Cloudsley-Thompson, J. L. \& ChadwiCk, M. J. (1964). Life in Deserts. Foulis, London: xvi +218 pp., illustr.

LAWrENCE, R. F. (1959). The sand-dune fauna of the Namib desert. S. Afr. J. Sci., 55, pp. 233-9.

Rivnay, E. (1964). The influence of Man on insect ecology in arid zones. Ann. Rev. Ent., 9, pp. 41-62.

SChmidt-Nielsen, K. (1964). Desert Animals: Physiological Problems of Heat and Water. Clarendon Press, Oxford: $\mathrm{xv}+277$ pp., illustr.

Stebing, E. P. (1954). Forests, aridity and deserts. Pp. 123-8 in Biology of Deserts (Ed. J. L. Cloudsley-Thompson). Institute of Biology, London: iv +224 pp., illustr.

\title{
Polarization Within the Environmental Movement in the U.S.A.
}

In the 15 June 1977 issue of Forbes magazine there appeared a remarkable article written by Jean A. Briggs entitled 'The Price of Environmentalism-The Backlash Begins'. It points out several interesting facts which have to be kept in mind by those who look for the development of enlightened environmentalism in over-developed countries in the coming years. In this the USA, despite its high rate of unemployment, is somewhat ahead of the Western European industrialized countries.

There are two main reasons why environmentalism in the USA is now going through a phase of rapid restructuring:

(a) The claim of environmentalists that their restrictions produce jobs rather than eliminate them is coming seriously to be doubted, as there is increasing evidence that jobs are lost or will be lost because industrial plants cannot be built or further operated owing to environmental costs or restrictions.

(b) The previous environmentalist coalition is separating into at least two rather different groups. Thus we have the 'purists', also called 'preservationists', who go to the extreme of describing our present society as 'wasteful, alienating, and polluting.' Their high priests, men like Barry Commoner and E.F. Schumacher, still have followings, but are not unchallenged' (quoted from J. A. Briggs). On the other hand the second group, the conservationists (whose founding father was the great Gifford Pinchot), promote development with environmental safeguards. Prominent members of this group include Secretary of the Interior Cecil Andrus, who, when interviewed by Forbes, said: 'We are a resource-development nation, not like some who use others' resources. It's a matter of doing it properly.' The group of conservationists is apparently growing rapidly, and governors of States or Senators who were previously sensitive to environmental issues are joining it -including Governor Edmund Brown of California, Governor Michael Dukakis of Massachusetts, and Senator Gary Hart of Colorado. Brown for instance declared: '. . limits apply not only to business and government, they apply to environmental groups as well.
The problem with the first-mentioned group, the purists, seems to be that they expect government and politicians to go 100 per cent with them to the idealistic target. But more and more spokesmen point out that even to reach Environmental Protection Agency (EPA) standards would cost thousands of millions of dollars- which would have to be provided by the U.S. public and industry. Moreover the expenditure of such large sums would be rather useless, in not really changing the quality of air or of already swimmable and fishable rivers or lakes to any measurable extent.

The Chairman of Du Pont estimates that some $30 \%$ of their projected ten thousand million dollars capital budget for 1976-85 will go for pollution and noise control, but that only one-quarter of this expenditure will yield any identifiable benefit to the environment. Further, Du Pont points out that committing $30 \%$ of their capital budget to environmental protection instead of to manufacturing will lead to higher prices and fewer jobs. Because pollution control expenditures are more capital-intensive than manufacturing expenditures, they employ fewer people; but even more important, there is nobody employed 'downstream'. Normally, it is the rule in manufacturing industries that there is one additional job created downstream for each job in a plant making a product.

It seems clear that, as long as a regulation produces a benefit, it should not be challenged by society. But in many cases, laws have been passed in haste or on the basis of very incomplete technical knowledge. So we conclude that, in the triangle of public-government-industry, wherever the assessment of environmental issues is carried out, strict rules must apply but improved understanding and cooperation should emerge as well.

Dieter G. AltenPoHL, Technical Director
Schweizerische Aluminium AG
Feldeggstrasse 4
8034 Zürich
Switzerland.
Schweizerische Aluminium AG Switzerland. 